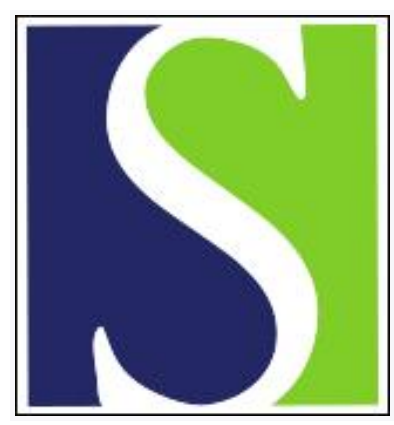

Scand J Work Environ Health 1990;16(3):203-207

https://doi.org/10.5271/sjweh.1793

Issue date: 01 Jun 1990

Ethylenethiourea in air and in urine as an indicator of exposure to ethylenebisdithiocarbamate fungicides.

by Kurttio $P$, Savolainen $K$

Affiliation: National Public Health Institute, Department of Environmental Hygiene and Toxicology, Kuopio, Finland.

This article in PubMed: www.ncbi.nlm.nih.gov/pubmed/2382123

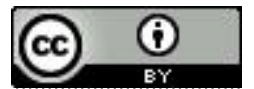




\title{
Ethylenethiourea in air and in urine as an indicator of exposure to ethylenebisdithiocarbamate fungicides
}

\author{
by Päivi Kurttio, MSc, Kai Savolainen, MD ${ }^{1}$
}

\begin{abstract}
KURTTIO P, SAVOLAINEN K. Ethylenethiourea in air and in urine as an indicator of exposure to ethylenebisdithiocarbamate fungicides. Scand J Work Environ Health 1990;16:203-7. Ethylenethiourea (ETU) is a ubiquitous impurity of the ethylenebisdithiocarbamate (EBDC) fungicides widely used in agriculture and forestry. In the present study, ETU was used as a measure of the exposure to EBDC on potato farms and in pine nurseries during the application of EBDC fungicides and the weeding of the sprayed vegetation. Biological and hygienic monitoring was carried out through the analysis of ETU in the breathing zone and the urine of exposed workers. Even if the concentrations of ETU in the ambient air of pine nurseries exceeded those of potato farms, the concentrations of ETU in the urine of potato farmers exceeded those of pine nursery workers. This result may have been due better protective equipment in the pine nurseries. The excretion rate was $6-10 \mathrm{ng} / \mathrm{h}$ during the first $60 \mathrm{~h}$ after the cessation of exposure, and it diminished thereafter to $0.2 \mathrm{ng} / \mathrm{h}$ over a $22-\mathrm{d}$ observation period.
\end{abstract}

Key terms: biological monitoring, occupational hygiene, pine nurseries, potato farms.

Ethylenebisdithiocarbamates (EBDC) are common agricultural fungicides, and they are also widely used in forestry. Ethylenethiourea (ETU), a degradation product and byproduct of the manufacturing of EBDC, is formed in the presence of moisture and oxygen in EBDC formulations. EBDC are also metabolized to ETU in the mammalian organism $(1-3)$. ETU itself is used as an accelerator in the rubber vulcanization process. It is also used in dyes, pharmaceuticals, synthetic resins, and electroplating baths (3). Even though the acute toxicity of pure EBDC is low (3), the health of workers may be jeopardized due to exposure to ETU (4). Moreover, EBDC and ETU may be readily absorbed via the lungs, the gastrointestinal tract, and the skin (5).

ETU causes thyroid hyperplasia and marked alterations in the levels of thyroid hormones in the serum of humans and experimental animals $(6,7)$, and it is also known for its teratogenic potency (8). ETU is weakly genotoxic in several test systems $(9,10)$, but is a clear carcinogen in experimental animals (11). The National Institute for Occupational Safety and Health (NIOSH) in the United States considers ETU a potential human carcinogen (12).

In this study, four groups of workers were examined during and after exposure to EBDC fungicides. Biological and hygienic monitoring of the exposure was carried out through measurements of ETU in the ambient air and in urine of EBDC-exposed workers. The objective of the study was to evaluate the internal dose

\footnotetext{
1 National Public Health Institute, Department of Environmental Hygiene and Toxicology, Kuopio, Finland.

Reprint requests to: Ms P Kurttio, National Public Health Institute, Department of Environmental Hygiene and Toxicology, PO Box 95, SF-70701 Kuopio, Finland.
}

of ETU and the potential hazard to the health of workers from exposure to EBDC fungicides or ETU.

\section{Subjects and methods}

\section{Subjects and the application of the pesticide}

The exposure of two groups of pesticide applicators to EBDC fungicides was studied on 38 potato farms. Group I comprised nine men (average age 40 years, body weight $79 \mathrm{~kg}$, and height $178 \mathrm{~cm}$ ) studied during the summer of 1986. In group II, there were 29 men (average age 41 years, body weight $83 \mathrm{~kg}$, and height $177 \mathrm{~cm}$ ), and the study was carried out during the summer of 1987. Exposure to EBDC was also studied in a group of workers from four pine nurseries (group III). It consisted of five men (mean age 33 years, body weight $77 \mathrm{~kg}$, and height $177 \mathrm{~cm}$ ) who applied pesticide in the summer of 1986. A final group (group IV) consisted of 15 women (mean age 44 years, weight $71 \mathrm{~kg}$, and height $162 \mathrm{~cm}$ ) who weeded in the pine nurseries in the summer of 1987.

The protection of the pesticide applicators on the potato farms (groups I and II) was usually poor, and they never wore respirators to decrease exposure via inhalation. The pine nursery workers (group III) wore respirators (equipped with a particle filter), rubber boots, leather or rubber gloves, and overalls.

The potato fields were sprayed with a $56 \%$ mancozeb or a $80 \%$ maneb formulation. In the pine nurseries, only a maneb formulation was used. The weeding of the vegetation in the nurseries was carried out two weeks after the treatment of the fields with maneb. There was always an interval of several weeks between subsequent sprayings so that each worker was studied after a single application or exposure period. 
A tractor-pulled pump-operated spray equipped with a 300-500 I tank was used for the pesticide application. Pressure during the spraying was $2-4 \mathrm{kp} / \mathrm{cm}^{2}$ $\left(2-4 \mathrm{kp}=20-40 \mathrm{~N}=20-40 \mathrm{~kg} \cdot \mathrm{ms}^{-2}\right)$. The height of the nozzles was about $50 \mathrm{~cm}$ above the ground. The mean areas of the sprayed fields were 4 ha (group I) and 14 ha (group II) on the potato farms and 3 ha in the pine nurseries (group III). The average application time was 2 (groups I and III) or 4 (group II) h. The workers in group IV did not carry out any application of EBDC fungicides.

\section{Sampling}

Air samples for the analyses of ETU in the breathing zone of the workers and in the cabin of the tractors used for fungicide application were collected on membrane filters $(0.8 \mu \mathrm{m}$, Millipore) with a portable pump (MSA model S) with a flow of $2-3 \mathrm{l} / \mathrm{min}$. The sampling times were equivalent to the application times. Air samples were collected with a Resiprotor ${ }^{\circledast}$ pump $(20 \mathrm{l} / \mathrm{min}$ ) during the weighing and the mixing of the pesticide with water $(5-15 \mathrm{~min})$.

Group I collected all urine of 10 subsequent urine samples voided after the cessation of application (average follow-up time was $59 \mathrm{~h}$ ). Group II collected four 24-h urine samples during the 22-d period (days 1,8 , 15 , and 22) after the cessation of EBDC exposure. The pine nursery workers in group III collected all urine from 5-15 urinations after the cessation of exposure (average follow-up time was $44 \mathrm{~h}$ ). A 24-h urine sample was collected from every nursery weeder in group

Table 1. Ethylenethiourea (ETU) concentrations in the breathing zone of four groups of workers exposed to ethylenebisdithiocarbamates.

\begin{tabular}{|c|c|c|c|c|c|c|}
\hline \multirow{3}{*}{$\begin{array}{l}\text { Exposure } \\
\text { group }{ }^{\mathrm{a}}\end{array}$} & \multicolumn{6}{|c|}{ ETU $\left(\mu \mathrm{g} / \mathrm{m}^{3}\right)$} \\
\hline & \multicolumn{3}{|c|}{ Spraying } & \multicolumn{3}{|c|}{ Weighing and mixing } \\
\hline & $\begin{array}{l}\text { Number } \\
\text { of } \\
\text { workers }\end{array}$ & Mean & SEM & $\begin{array}{c}\text { Number } \\
\text { of } \\
\text { workers }\end{array}$ & Mean & SEM \\
\hline $\begin{array}{l}\text { I } \\
\text { II } \\
\text { III } \\
\text { IV }\end{array}$ & $\begin{array}{r}10 \\
13 \\
5 \\
14\end{array}$ & $\begin{array}{l}0.14 \\
0.80 \\
0.60 \\
0.01\end{array}$ & $\begin{array}{l}0.06 \\
0.30 \\
0.39 \\
0.003\end{array}$ & $\begin{array}{l}10 \\
13 \\
13\end{array}$ & $\begin{array}{c}0.87 \\
0.90 \\
1.81 \\
\ldots\end{array}$ & $\begin{array}{l}0.20 \\
0.20 \\
0.58\end{array}$ \\
\hline
\end{tabular}

a Groups I and II: potato field applicators, group III: pine nursery applicators, and group IV: pine nursery field weeders.

Table 2. Excretion of ethylenethiourea (ETU) in urine during the first $24 \mathrm{~h}$ after the cessation of exposure to ethylenebisdithiocarbamates.

\begin{tabular}{lrr}
\hline \multirow{2}{*}{$\begin{array}{l}\text { Exposure } \\
\text { group }\end{array}$} & \multicolumn{2}{c}{ ETU (ng/24 h) } \\
\cline { 2 - 3 } & Mean & SEM \\
\hline I & 3746 & 885 \\
II & 3368 & 945 \\
III & 2172 & 1047 \\
& 498 & 203 \\
\hline
\end{tabular}

a Group I and II: potato field applicators, group III: pine nursery applicators, and group IV: pine nursery weeders.
IV in a manner similar to that used for group II (days $1,8,15$, and 22). All the workers also gave a blank urine sample prior to the beginning of the exposure.

\section{Analysis for ethylenethiourea}

The analysis of ETU in EBDC fungicides on filters and in the urine samples was carried out with a high-pressure liquid chromatograph (HPLC) as described earlier (13). Briefly, a filter and $2 \mathrm{ml}$ of distilled water were kept in a sonicating water bath and mixed.

The ETU in the urine samples $(10 \mathrm{ml})$ was evaporated to dryness. Thereafter, $2 \mathrm{ml}$ of methanol and $150 \mathrm{mg}$ of silica gel were added. Methanol was evaporated, and the sample was transferred to an aluminum oxide column and eluted with $2 \%$ methanol in dichloromethane. The eluate was evaporated, and the sample was dissolved in $0.5 \mathrm{ml}$ of water. Recovery (mean $50 \%$ ) of each separate sample preparation was measured with the use of urine spiked with a known amount of ETU. The spiked sample was prepared and analyzed in the same manner as the other samples.

To determine the amount of ETU impurity in the formulations, we weighed a known amount of EBDC formulation in a 50-I measuring flask and diluted it with distilled water.

The HPLC analysis of ETU was carried out with a Hewlett Packard 1090 liquid chromatograph equipped with a diode array detector. The column was a reverse phase Hypersil 5 ODS $^{\circledR}$ (column length $25 \mathrm{~cm}$, internal diameter $4.6 \mathrm{~mm}$, Chrompack). The isocratic elution of $5 \%$ methanol in $0.05 \mathrm{M}$ ammonium acetate in water was used. The detection wavelength was $230 \mathrm{~nm}$. The detection limit for ETU was $100 \mathrm{pg} /$ injection; for ETU on a filter sample and in urine the detection limit was $8 \mathrm{ng} / \mathrm{sample}$ and $200 \mathrm{ng} / \mathrm{l}$, respectively.

\section{Analysis of the results}

The levels of ETU that were at the detection limit of the method but were too low to be reliably quantitated were considered to be at the detection limit, ie, $8 \mathrm{ng} /$ filter for an air sample and $200 \mathrm{ng} / \mathrm{l}$ for a urine sample. The means and standard deviations or the standard errors of the means of the concentrations of ETU in air and in urine were calculated. The slope of the elimination phase of ETU in urine was calculated for the first $60 \mathrm{~h}$ and for the whole 22-d follow-up period with the method of least squares.

\section{Results}

\section{Potato field applicators}

If it is assumed that the concentrations of ETU in the air were stable during the whole work period, the exposure via the lungs (ETU $\mu \mathrm{g} / \mathrm{m}^{3} \times$ time $\times 0.02 \mathrm{~m}^{3} /$ min breathing rate) was more than tenfold greater in group II $(5.2 \mu \mathrm{g})$ than in group I $(0.4 \mu \mathrm{g})$ (table 1$)$ because of the longer application time. The amounts of 


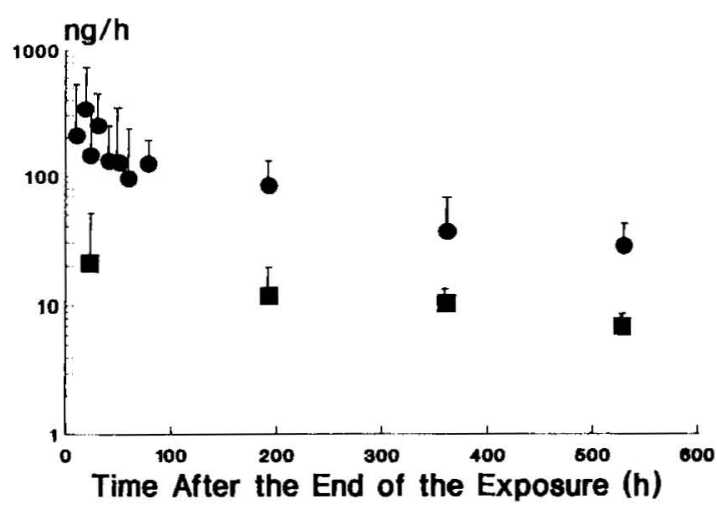

Figure 1. Excretion rate (means and standard deviations of the means) of ethylenethiourea (ETU) in the urine $(\mathrm{ng} / \mathrm{h}$ ) of potato field applicators (circles) (groups I and II) and pine nursery weeders (squares) (group IV) after exposure to ethylenebisdithiocarbamates during pesticide application (groups I and II) and the weeding of the sprayed vegetation (group IV). The ETU concentrations were at the detection limit in group IV after two weeks of follow-up (two last time points).

ETU in the urine of the men in these two groups show, however, that the absorbed amounts of EBDC fungicides metabolized to ETU were equal (table 2). The concentrations of ETU during the weighing and mixing of the pesticide ( $10 \mathrm{~min}$ at a time) was similar for both groups (table 1). Therefore, this work phase may have contributed considerably to the absorbed amount of the pesticide.

The concentrations of ETU in the urine of the potato field applicators were between $<0.2$ and $23 \mu \mathrm{g} / \mathrm{l}$. The decrease in the excretion rate of ETU was the most rapid between 20 and $40 \mathrm{~h}$ after the cessation of the exposure (figures 1 and 2 ). The average excretion rate of ETU was $6 \mathrm{ng} / \mathrm{h}$ during the first $60 \mathrm{~h}$ after the cessation of the exposure, and it diminished to $0.2 \mathrm{ng} / \mathrm{h}$ during the 22-d follow-up period, as indicated by the equations given in table 3 . The results suggest a twophase elimination for ETU groups I and II. Slow dermal penetration may have contributed to this result. The variation in the levels of ETU in the urine was great, and it did not allow for a reliable estimation of the elimination half-time of the urinary excretion of ETU (figures 1 and 2).

\section{Pine nursery applicators}

The concentration of ETU in the air during the weighing and mixing of pesticides was the highest in the breathing zone of the workers in group III (table 1). The average concentration of ETU in the breathing zone of these workers equaled the pooled concentration of ETU in the breathing zone of the potato field applicators [groups I and II combined 0.54 (SD 0.17) $\left.\mu \mathrm{g} / \mathrm{m}^{3}\right]$. The concentrations of ETU in the urine of

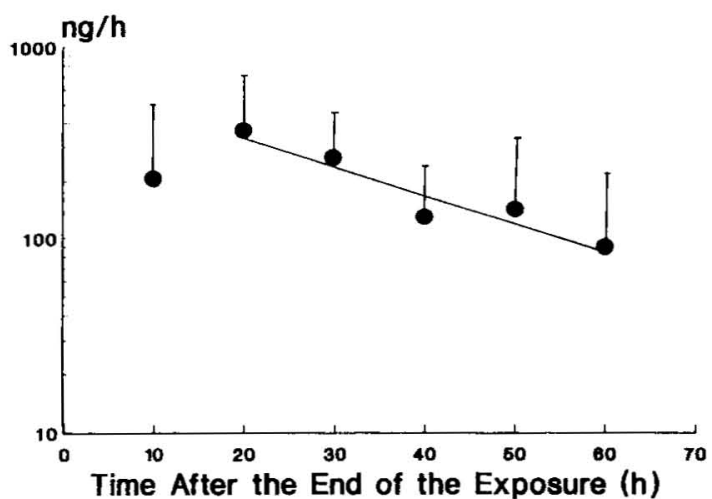

Figure 2. Excretion rate of ethylenethiourea (ETU) (means and standard deviations of the means) in the urine $(\mathrm{ng} / \mathrm{h})$ of potato field applicators (group 1) during $60 \mathrm{~h}$ after the cessation of exposure to ethylenebisdithiocarbamate fungicides. The first time point at $10 \mathrm{~h}$ after the cessation of the application was omitted from the analysis because of possible continuous exposure for a few hours after the application and because of the effect of dermal absorption. The regression equation is $y=-6 x+455$, where $y$ is the excretion rate of ETU $(n g / h), x$ is the time (h), and the correlation coefficient squared $\left(r^{2}\right)$ is 0.86 .

Table 3. Rate of the excretion of ethylenethiourea (ETU) in urine. The equation $y=a+b x$ gives the slope for the elimination of ETU for each worker group separately. [y=ETU in urine (ng/h), $x=$ time, $a=y$-intercept furinary excretion rate $(\mathrm{ng} / \mathrm{h})$ of ETU at the cessation of the exposure), $b=$ slope of the elimination]

\begin{tabular}{lccc}
\hline $\begin{array}{l}\text { Exposure } \\
\text { group }\end{array}$ & $\begin{array}{l}\text { Follow-up } \\
\text { excretion } \\
\text { time } \\
\text { (h) }\end{array}$ & \multicolumn{2}{c}{$\begin{array}{c}\text { Regression } \\
\text { coefficients }\end{array}$} \\
\cline { 3 - 4 } & $10-60$ & $\mathrm{a}$ & $\mathrm{b}$ \\
\hline II & $24-528$ & 455 & -6 \\
III & $20-50$ & 135 & -0.2 \\
IV & $24-528$ & 632 & -10 \\
& & 20 & -0.02 \\
\hline
\end{tabular}

a Groups I and II: potato field applicators, group III: pine nursery applicators, and group IV: pine nursery weeders.

group III were between $<0.2$ and $5.6 \mu \mathrm{g} / \mathrm{l}$. The excretion rate of ETU was $10 \mathrm{ng} / \mathrm{h}$ during the first $50 \mathrm{~h}$ after the cessation of the exposure (table 3 ).

\section{Pine nursery field weeders}

The concentration of ETU in the breathing zone of group IV exceeded the limit of detection only in four out of 14 samples. The highest air concentration of ETU was $0.04 \mu \mathrm{g} / \mathrm{m}^{3}$ (table 1). The concentrations of ETU in the 24-h urine samples exceeded the limit of detection in only four of the 60 samples. After two weeks (on day 15) ETU could not be detected in the urine samples. (See tables 2 and 3 and figure 1). Figure 1 indicates the marked difference in exposure to EBDC between the potato field applicators (groups I and II) and the pine nursery weeders. (See also table 3.) 
Concentration of ETU in maneb and mancozeb formulations

The concentrations of ETU in formulations containing maneb and mancozeb were 59 and $22 \mathrm{mg} / \mathrm{g}$ (5.9 and $2.2 \%$ ), respectively.

\section{Discussion}

The results from the present study showed that the exposure of all the workers exposed to ETU was clearly below the Finnish exposure limit, which is $0.2 \mathrm{mg} / \mathrm{m}^{3}$ for an 8-h workday with a ceiling value of $0.6 \mathrm{mg} / \mathrm{m}^{3}$ for $15 \mathrm{~min}$ (14). In the pine nurseries, the concentrations of ETU in the air were relatively high during the periods of pesticide application. However, the absorbed amounts of ETU and EBDC, as illustrated by the concentrations of ETU in the workers' urine, were smaller than those measured for the potato field applicators. The difference was probably due to the use of better protective equipment and clothes among the pine nursery workers. The significance of ETU impurity in EBDC formulations was probably minor because the amount of ETU in the EBDC formulations was small.

During the weeding of sprayed vegetation the probable route of exposure is via the skin. EBDC do not belong to the systemic fungicides, and they remain on plant surfaces (15). In addition, ETU has been found on plants treated with EBDC (16). However, intact ETU disappears from plants and soil with a half-time of less than one week and much more rapidly than EBDC, the half-time of which is four to eight weeks. The half-time of ETU derived from EBDC has been shown to be less than four weeks (17). Therefore, the exposure of the weeders was low, and probably mainly from EBDC fungicides rather than from intact ETU. In agreement with these observations, ETU was not detected on the clothes or on tiie skin of the weeders (data not shown). The small amounts of ETU in the breathing zones of the weeders could have been due to ETU that had biodegradated from EBDC in the soil $(3,17)$.

In this study, the excretion rate of ETU in urine was the highest during the first $60 \mathrm{~h}$ after the cessation of exposure. Gradually, the rate of the excretion declined. After $21 \mathrm{~d}$, only small amounts of ETU could be detected in the urine of the workers with the highest exposure. The analysis of the rate of excretion of ETU in urine revealed that, after the initial elimination phase of $60 \mathrm{~h}$, the decrease in the elimination rate of ETU was $0.2 \mathrm{ng} / \mathrm{h}$ over the whole follow-up period. This finding illustrates the slow rate of urinary elimination of ETU. The present sampling strategy did not allow for an accurate estimation of the urinary elimination half-time for ETU. In addition, the urinary excretion of ETU continued for a surprisingly long time after the cessation of the exposure to EBDC. The exposure to EBDC and ETU was not necessarily terminated, however, immediately after the pesticide application. The pesticide was usually stored in an unsheltered storage place where frequently used farming equipment was stored. Thus continuous exposure, mainly via the skin, may have played a role and may possibly explain the present results.

Two different phases could still be demonstrated in the urinary elimination of ETU. However, our estimate of the urinary elimination half-time of ETU of about $32-37 \mathrm{~h}$ differs from our earlier observation of the elimination half-time of ETU of about $100 \mathrm{~h}$ in another group of workers also exposed to EBDC and ETU (18). This difference may be due to the marked differences in the sampling strategies and the modes of exposure. The present results support the view that EBDC are metabolized to ETU in the human body because the exposure to ETU alone cannot explain the amounts of ETU found in the urine.

After the treatment of rodents with maneb, the amount of ETU excreted in the urine was 10-16\% of the dose $(2,19,20)$. The amount of ETU excreted in urine after the administration of ETU was 24$63 \%$ for different animal species $(2,21)$. Intestinal absorption of EBDC may not always be exactly proportional to the dose. For example, cations naturally occurring in food will decrease the absorption, especially at lower doses of EBDC (22). Thus the results on absorption in rodents do not directly apply to man. The elimination rate of different EBDC is complicated by the fact that mancozeb is more resistant to metabolic degradation than maneb (23). Thus, in agreement with the present results, the excretion of ETU is complex, and a clear correlation between concentrations of EBDC in air and ETU in urine cannot be assumed.

Earlier, EBDC, but not ETU, concentrations in the breathing zone, or on the clothes, of workers have been analyzed to estimate the occupational exposure to EBDC (24-28). The exposure limits for dithiocarbamate fungicides vary between 0.1 and $10 \mathrm{mg} / \mathrm{m}^{3}(25$, 29, 30).

Because ETU is a suspected human carcinogen, it is crucial to determine exposure to it whenever possible. Because of its biological properties and because of the complexity of the biotransformation of EBDC to ETU, ETU in urine is not, however, an ideal choice for the biological monitoring of exposure to EBDC or ETU. However, our measurements of ETU in air and urine indirectly reflect the amount of exposure to EBDC or ETU and show that even a small exposure to EBDC and ETU may result in measurable concentrations of ETU in urine. These measurable concentrations can then be used as a warning signal for exposure to a potentially dangerous substance. It would also be valuable to control the amounts of ETU impurity in EBDC formulations and to find alternatives for compounds which are transformed to ETU via biodegradation or biotransformation.

The measured amounts of ETU in urine in the present study do not, however, support the view that the 
observed levels of exposure to ETU and EBDC would readily jeopardize the health of exposed workers.

\section{Acknowledgments}

The authors wish to thank Ms T Korhonen and Ms $P$ Mustonen for their skillful help in the analyses of ETU in the air and urine samples.

Financial aid by the Finnish Work Environment Fund and the North-Savo Regional Fund of the Finnish Cultural Foundation is gratefully acknowledged.

\section{References}

1. Engst R, Schnaak W. Studies on the metabolism of the ethylenebisdithiocarbamate fungicides maneb and zineb. Z Lebensm Unters Forsch 1970;143:99-103.

2. Jordan LW, Neal RA. Examination of the in vivo me tabolism of maneb and zineb to ethylenethiourea (ETU) in mice. Bull Environ Contam Toxicol 1979;22:271-7.

3. World Health Organization. Dithiocarbamate pesticides, ethylenethiourea, and propylenethiourea: a general introduction. Geneva: World Health Organization, 1988. (WHO environmental health criteria; no 78.)

4. Fishbein L. Environmental health aspects of fungicides: I. dithiocarbamates. J Toxicol Environ Health 1976; $1: 713-5$.

5. Plunkett ER. Handbook of industrial toxicology. London: Heyden \& Son Limited, Spectrum House, 1976.

6. Kurttio P, Savolainen K, Tuominen R, et al. Ethylenethiourea and nabam induced alterations of function and morphology of thyroid gland in rats. Arch Toxicol Suppl 1986;9:339-44.

7. Smith DM. Ethylenethiourea: thyroid function in two groups of exposed workers. Br J Ind Med 1984;41: $362-6$.

8. Khera KS. Ethylenethiourea-induced hindpaw deformities in mice and effects of metabolic modifiers on their occurrence. J Toxicol Environ Health 1984;13:747-56.

9. Klopman G, Contreras R, Rosenkratz HS, Waters MD. Structure-genotoxic activity relationships of pesticides: comparison of the results from several short-term assays. Mutat Res 1985;147:343-56.

10. International Agency for Research on Cancer. Genetic and related effects: an updating of selected IARC monographs from volumes 1 to 42. Lyon: International Agency for Research on Cancer, 1987. (IARC monographs on the evaluation of carcinogenic risks to humans; suppl 6.)

11. Innes JRM, Ulland BM, Valerio MG, et al. Bioassay of pesticides and industrial chemicals for tumorigenicity in mice. J Natl Cancer Inst 1969;42:1101-14.

12. Stein HP, Bahlman LJ, Leidel NA, Parker JC, Thomas AW, Millar JD. Ethylenethiourea (ETU). Am Ind Hyg Assoc J 1978;39:A34-8.

13. Kurttio P, Vartiainen T, Savolainen K. A high pressure liquid chromatographic method for the determination of ethylenethiourea in urine and on filters. Anal Chim Acta 1988;212:297-301.
14. Työsuojeluhallitus. Työpaikan ilman eppuhtaudet [Impurities in workplace air]. Turvallisuustiedote 1981;3:12.

15. Engst R, Schnaak W. Residues of dithiocarbamate fungicides and their metabolites on plant foods. Residue Rev 1974;52:45-67.

16. Pease HL, Holt RF. Manganese ethylenebis(dithiocarbamate) (Maneb)/ethylenethiourea (ETU) residues studies on five crops treated with ethylenebis(dithiocarbamate) (EBDC) fungicides. J Agric Food Chem 1977;25:561 - 7.

17. Rhodes RC. Studies with manganese (14C)ethylenebis(dithiocarbamate)((14C)maneb) fungicide and $\left(14^{\circ} \mathrm{C}\right)$ ethylenethiourea $((14 \mathrm{C}) \mathrm{ETU})$ in plants, soil, and water. J Agric Food Chem 1977;25:528-33.

18. Kurttio P, Vartiainen T, Savolainen K. Occupational hygienic and biological monitoring of exposure to ethylenebisdithiocarbamate fungicides and ethylenethiourea. Br J Ind Med (in press).

19. Autio K, Pyysalo H. Application of $\gamma$-irradation technique in the identification of some metabolites of maneb in mice. J Agric Food Chem 1983;31:568-71.

20. Camoni I, Cicero AM, Di Muccio A, Dommarco R. Measurement of urinary excretion of ethylenethiourea (ETU) in zineb-treated rats. Med Lav 1984;75:207-14.

21. Iverson $F$, Khera $\mathrm{KS}$, Hierlihy SL. In vivo and in vitro metabolism of ethylenethiourea in the rat and the cat. Toxicol Appl Pharmacol 1980;52:16-21.

22. Brocker ER, Schlatter $\mathrm{CH}$. Influence of some cations on the intestinal absorption in urine of rats. J Agric Food Chem 1979;27:303-6.

23. Dich J, Meijer C. Växtskyddsraporter, Jordbruk [Plant protection reports, agriculture]. 1982; 20:20-32.

24. Hagmann M, Schlatter C. Feldmessungen zur Bestimmung der Belastung von Spritzpersonal mit Pflanzenschutzmitteln. Chimia 1983;37:135-40.

25. Maini P, Boni R. Gas chromatographic determination of dithiocarbamate fungicides in workroom air. Bull Environ Contam Toxicol 1986;37:931-7.

26. Nilsson C-A, Eriksson K, Kragh E, Nygren O. Exponering för damm och mancozeb vid upptagning av tallplantor [Exposure to dust and mancozeb during field operations in pine nurseries]. Umeå (Sweden): Institute of Occupational Health, 1986. (Undersökningsrapport 1986:37.)

27. Nilsson C-A, Nygren O, Sikström E. Determination of mancozeb in air: occupational exposure during its use in control of potato late blight. Chemosphere 1987;16: $2423-8$.

28. Kangas J, Koskinen A, Husman K. Exposure of Finnish forestry nursery workers to quintozene and maneb. In: Tordois WR, van Heemstra EAH, ed. Field worker exposure during pesticide application. New York, NY: Elsevier, 1980:79-84. (Studies in environmental sciences; no 7.)

29. Health and Safety Executive. Guidance note EH 40/88 from the Health and Safety Executive, occupational exposure limits 1988. London: Health and Safety Executive, 1988. (ISBN 0-11-885404-6.)

30. Deutsche Forschungsgemeinschaft. Maximale Arbeitsplatzkonzentrationen und Biologische Arbeitsstofftoleranzwerte 1988. Bonn: Deutsche Forschungsgemeinschaft, 1988. ISBN-3-527-27365-4.

Received for publication: 11 October 1989 